\title{
疲労き裂進展挙動のSEM画像処理援用動的直接観察*
}

\section{菅田 淳**}

Direct SEM Observation of Fatigue Crack Growth Behavior using Image Processing Technique / Atsushi SUGETA

Key words: fatigue, crack growth mechanism, direct SEM observation, image processing technique, quantitative analysis, crack tip opening displacement, deformation near crack tip

\section{1.は じめ に}

疲労き裂進展は本来，局所的な現象であるためその機構 を解明するには走査型電子顕微鏡 (SEM) 等の高倍率観察 装置による微視的直接観察が有効な手段である。これまで に多くの研究が行われ，疲労き裂進展モデルが提案される とともに，き裂先端の開口量であるき裂先端開口変位 (Crack Tip Opening Displacement, CTOD) が一定振幅 荷重および変動荷重のいずれにおいてもき裂進展量を直接 支配する微視的支配パラメータであることが明らかにされ ている ${ }^{1)}$ 10)。乙かしながら，従来の観察ではき裂像の写真 撮影に少なくとも数秒の露出時間を要するため, 動的直接 観察の場合に执いても繰返し速度はたかだか $0.1 \mathrm{~Hz}$ 程度 にとどまっていた。 写真画像からのき裂開口変位，き裂進 展量などの定量解析には, 多大の労力と時間を要し，しか も目視による測定では客観性が損なわれる可能性がある. また，き裂進展機構の解明のために必要不可欠と考光られ るき裂先端近傍の变形状態の定量解析については, その測 定，処理の困難さからほとんど行われていないようであ る.

そこで，菊川，城野らにより作製された電界放射型走査 電子顕微鏡内疲労試験装置を用い，新たに電子顕微鏡の画 像信号を高速で A/D 変換し，マイクロコンピュータに取 り込み, 画像処理を行ら試験装置システムを構築し, 疲労

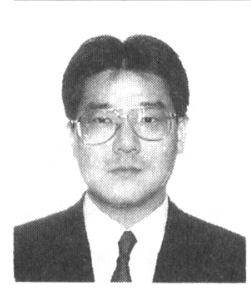

$*$ 原稿受付 平成 7 年 2 月 13 日

** 大阪大学工学部 (吹田市山田丘 2-1) 1983 年大阪大学大学院工学研究科機械工学専 攻前期課程修了, 工学博士。1992 年大阪大学 工学部機械工学科講師, 1994 年助教授, 現在 に至る。研究分野：材料強度学, 疲労機構の解 明
き裂進展挙動の動的直接観察を行い,き裂開口変位やき裂 先端近傍材料の変形量の定量解析を試みた ${ }^{11) \sim 13)}$.

\section{2. 試験装置および画像計測法}

図 1 に電界放射型走査電子顕微鏡に装着可能な電気油圧 サーボ式引張圧縮疲労試験機の概略図を示す。一般の試験 機のように，アクチュエータのシリンダと試験片の一端を 固定し他端にピストンにより荷重を加えた場合，試験片の 変位のために高倍率で観察している時には, 試験片中央部 のき裂は視野から外れて観察が困難となる。そこで本疲労 試験装置は，試験機を駆動したままで動的直接観察ができ るよう以下の工夫をしている。図中 (2) の試験片は一方を (9)で示すピストンに他方を (10)で示すシリンダに連結され て扰り，このピストンとシリンダの両者を反対方向に運動 させ，その相対移動量を調整することにより，観察部分の 荷重軸方向の移動成分をほ涂去している。ささらに，機械 的方法で除去できない微小な移動量については，走査電子 顕微鏡の観察視野をき裂に追随させるように電気的操作を 行らことで相殺し, 繰返し荷重下でも試験片観察部が視野 内で静止するよ5工夫されている . 疲労試験は, 動的な 繰返し荷重下に扣いて最大荷重時拈よび最小荷重時にき裂 画像の計測が行えるよう台形波を用いて行っている.

図 2 に試験装置のシステムブロック線図を示す。 SEM の 2 次電子信号は高速 Direct Memory Access 型 A/D 変 換器（分解能 12 bit）を介してマイクロコンピュータ（記 憶容量 16 Mbytes）へ転送される. 最高変換速度は $2.5 \mu \mathrm{s}$ であり，1 画面縦 490 画素 $\times$ 横 200 画素の画像データを取 り込导場合には, その所要時間は $0.245 \mathrm{~s}$ となるした がって台形波に批将大最大扣よび最小荷重の保持時間をこ の時間に設定することにより荷重繰返し速度約 $2 \mathrm{~Hz}$ の試 


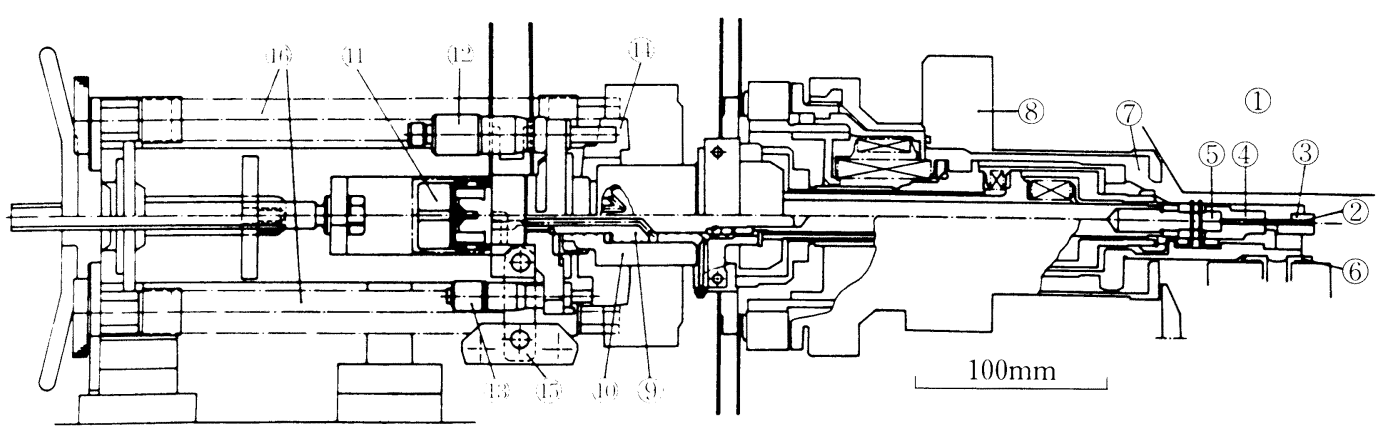

(1) 電界放射型走查電子影微鏡, (2) 試験片, (3) シリンダ側チャック，(4)ピストン側チャック，(5)ロードセル， (6) 試料台, (7) 予備排気絮, (8) 試験機取付けフランジ, (9) ピストン, (10)シリンダ, (11)サーボバルブ, (12) 微動マ イクロメータ，(13)粗動マイクロメータ，(14)環状ビーム，(15) 自在継手，(16)釣合いばね

図 1 走查電子顕微鏡装着型引張王縮疲労試験機

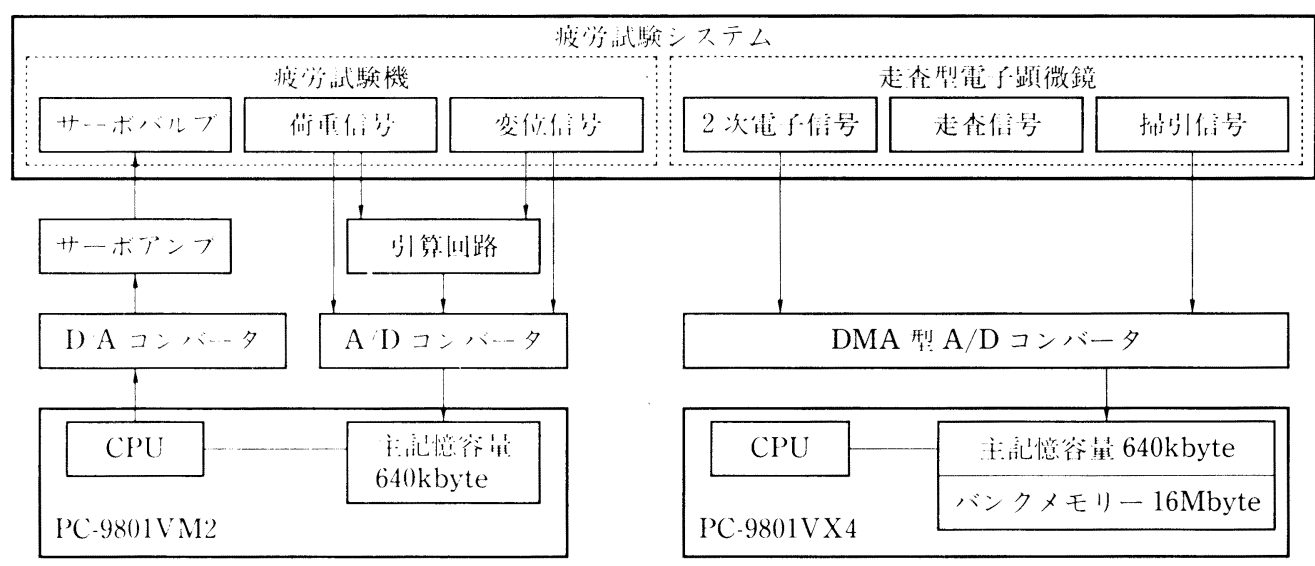

図 2 疲労試験装置扣よび画像計測システムのブロック線図

験が可能である．しかしながら，走査速度を速くすると電 子顕微鏡画像の解像度が低下寸るため, 十分な解像度の画 像を取り込をには実質 $1 \mathrm{~Hz}$ 程度が限界となる． 1 画面の 画素数を上記に設定することにより最大 20 画面の連続取 込みが可能である。一般には，データのサンプリング間隔 と走査信号とが必ずしも同期しないため，取り込んだ 1 次 元的な信号から 2 次元的な画像に再構成する場合，各走査 線に対応寸る行の開始点が定まらず機械的な配列では場合 によっては斜めにずれた画像として再生されることにな る. ここでは，2 次電子信号のブランキング部を検出し， 画像の再構成を行っている。 また，連続画面データの分割 は同時に計測した掃引信号の立下がりゼロクロス点を検出 し，1 画面の開始点として行っている.

試験には一方向性けい素鋼板の CCT 試験片を用い，表 面にはSEM の 2 次電子像をより鮮明にするため厚さ 5 $\mathrm{nm}$ 程度の金を蒸着し，さらに変形計測用の標点として酸 化マグネシウムを付着させている.

\section{3. 画像解析手法および適用例}

走査電子顕微鏡により得られた疲労き裂画像を用いた定 量解析として，き裂開口変位 (COD) 打よびき裂先端開口 変位 (CTOD) の計測ならびに複数画像の比較によるき裂

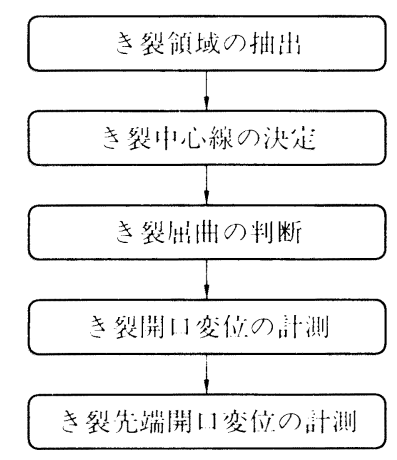

図 3 き裂開口量解析アルゴリズム

先端近傍の変形量の計測を行った.

\section{1 き裂開口量の計測}

疲労き裂開口量の解析アルゴリズムを図 3 に示す. 図 4 は画像解析の対象とした疲労き裂の SEM 画像であり, 図 5 はその輝度分布を示したものである. 輝度値の低い方が き裂領域に, 高い方が酸化マグネシウム標点領域に対応 し，その中間に試験片表面の輝度が分布している. 試験片 表面の輝度分布は広範囲にわたり，き裂領域の輝度分布と 重なっているため, き裂領域の抽出のための 2 值化処理に おけるしきい値を自動的に決定するのは困難であり，ここ ではマニュアル操作によりしきい值を決定した．図 6 はし きい值を 128 とした時の 2 值化画像であり，き裂以外の領 


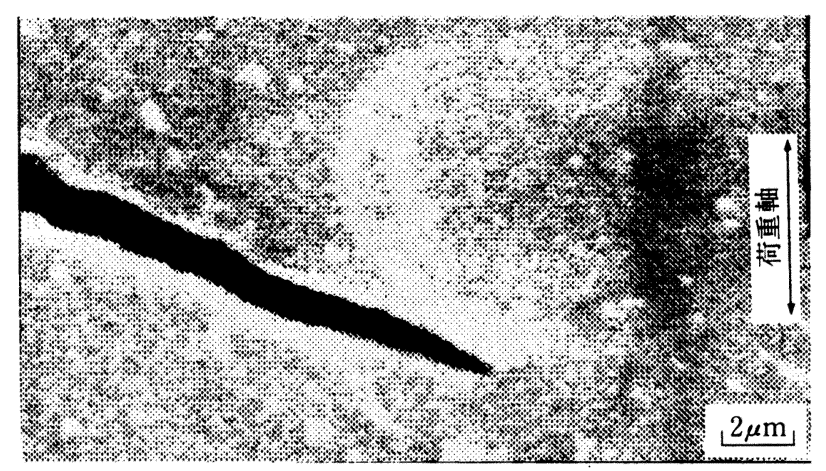

图 4 疲労さ裂の SEM 画像例

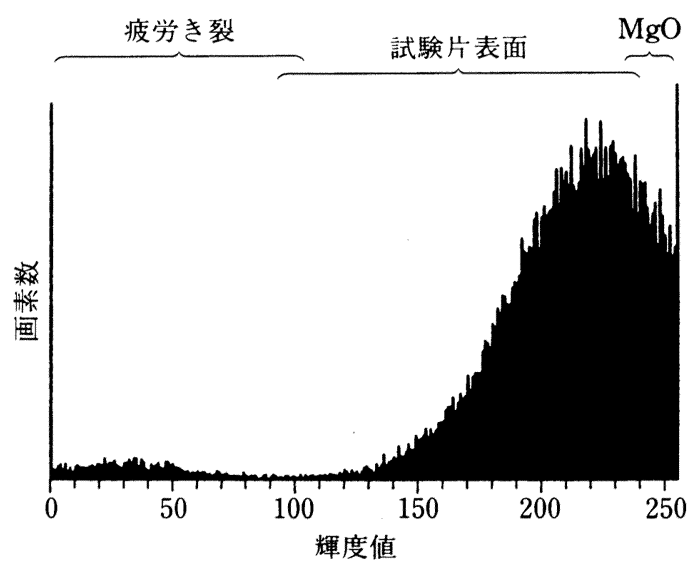

図 5 SEM 写真の輝度分布

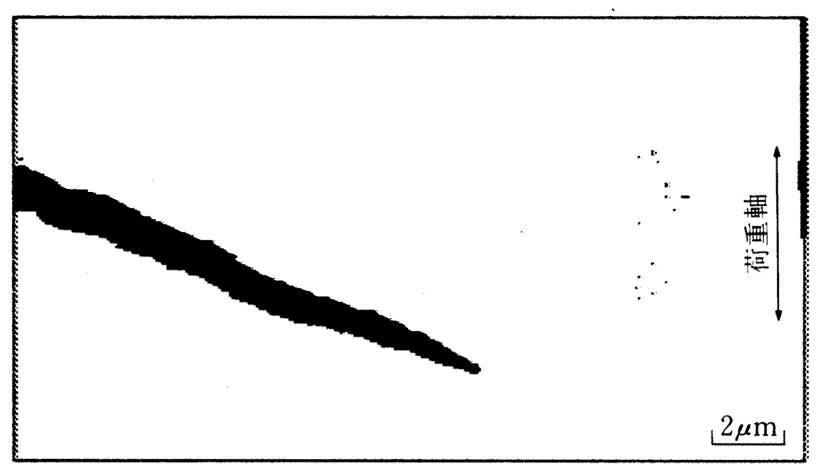

图 62 值化処理後の画像

域も抽出されているが，ここでは面積が最大の領域をき裂 として認識し解析対象として選んでいる.

このよらに認識したき裂領域を用いて CODを計測す る. COD は図 7 に示すようにき裂の中心線（一点鎖線） に垂直な方向のき裂開口量として定義する。一般にき裂は 屈曲を綝り返しながら進展するため, COD の計測を行ら ためには，まずき裂の中心線を求める必要がある．き裂中 心線の決定は，まずき裂を画素幅の微小領域に分割し，そ の各微小領域の重心を結んだ曲線を考光, この曲線と曲線 の両端を結んだ直線との荷重軸方向の差がき裂開口変位の 半分以上ある場合をき裂屈曲と判断する. この操作を絽返 乙全き裂屈曲点を求め, 屈曲点に扰ける微小領域の重心を 結ぶことによりき裂全体に対する中心線としている. 図 8 にき裂開口变位の計測例を示す. 中央が抽出されたき裂領

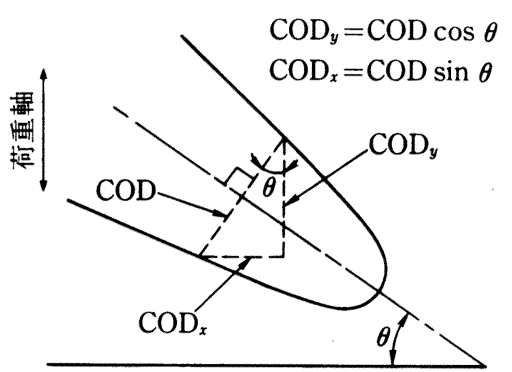

図 7 裂開口変位 $(C O D)$ の定義

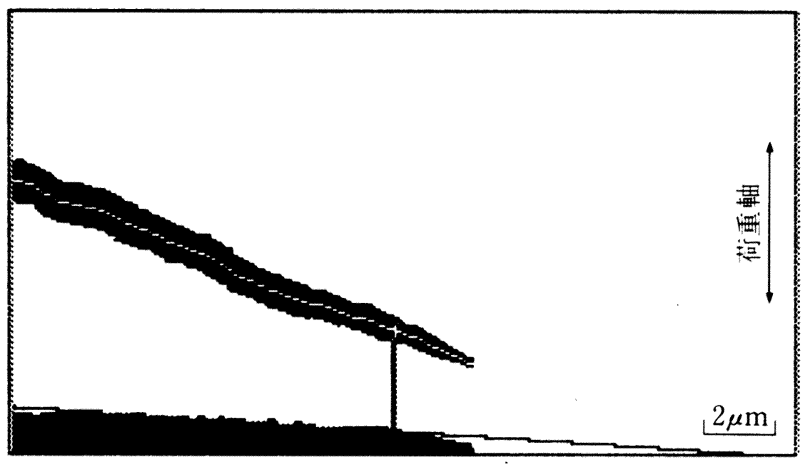

図 8 裂開口変位の計測例

域であり，下図が計測された CODである，COD はき裂 先端に向かって緩やかに減少していき，き裂先端近傍で急 激に減少している.このような COD の急激な減少が認め られる位置でのき裂開口変位をき裂先端開口変位 （CTOD）と定義する. 実際の解析では，き裂先端から 10 画素除いた後方のき裂領域に対する COD 曲線を図中実線 で示すよらに直線近似し，き裂先端後方に扔いて最初に実 線と COD 曲線とが交わる位置での開口変位として CTOD を定義している. 本例では, CTODはき裂先端から 1.25 $\mu \mathrm{m}$ 後方の位置で, $0.51 \mu \mathrm{m}$ と計測された. この值は, SEM 写真上で直接計測した值とよく一致しており, 画像 処理によるき裂先端開口変位の自動計測が可能であること がわかる.

\section{2 裂先端近傍の变形 2 の解析}

最小荷重負荷時と最大荷重負荷時に計測された画像から 疲労き裂先端近傍の变形状態の解析を試みた. 解析アルコ リズムを図 9 に示す. 変位量の解析は, 2 つの画像を重 ね，画像間での対応づけを取って行った．菊川，城野およ び筆者のこれまでの研究から, 荷重軸にほぼ直角に進展す る Mode I き裂の前方領域では, すべり変形が起こらない ことが明らかにされている5 . そこで 2 画像の重ね合わせ は, き裂前方の複数個のマグネシウムの位置を重ね合わせ ることにより行った. 2 枚の画像間の対応点を探索するた めに, 最大荷重時に得られた画像中に図 10 に示すよらな 空領域（糈 51 画素, 横 51 画素）を設定し, この空領域を テンプレートとして取りだし, 最小荷重時に得られた画像 中に重ね合わせ探索を行った。き裂画像の計測は通常最小 荷重時, 最大荷重時の順で行っており, 变位量解析におい 


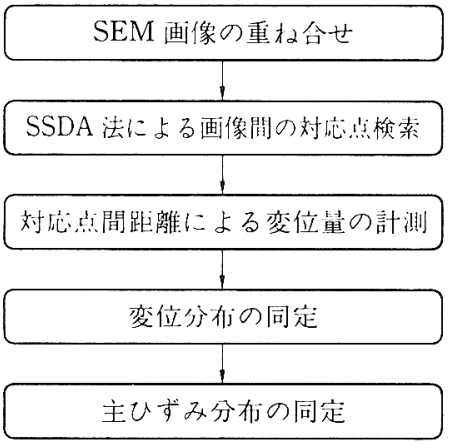

図 9 裂先端近傍変形解析のアルゴりズム

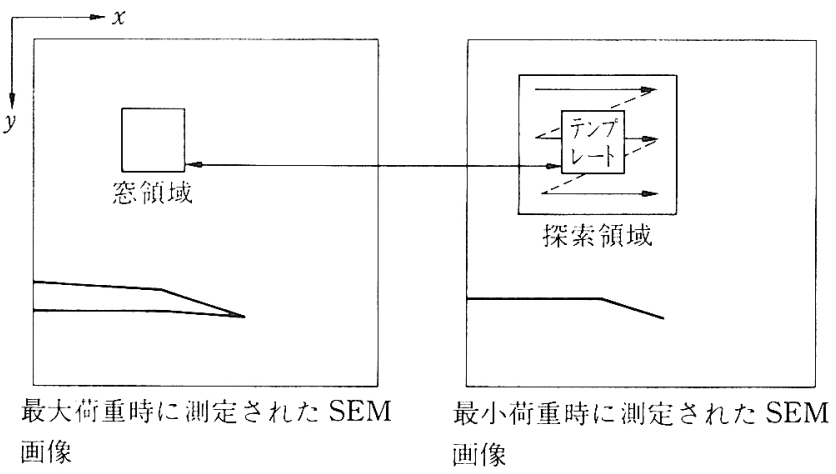

図 10 対応点の探索方法

ては，最小荷重時を基に最大荷重時の画像に対して対応点 探索を行らのが一般であると考克られる。しかしながら， SEM から得られる画像の領域に制限があり, 変形前の最 小荷重時の画像を基に探索した場合, 変形後の最大荷重時 の画像内に対応点が存在しない場合がある。したがって, 上述の上らにここでは，必ず対応点が存在するように最大 荷重時の画像をとにして2 画像間の対応点探索を行って いる。 李た，最小荷重時に得られた画像の全領域に対して 探索を行うのは時間がかかるので，空領域の中心座標を中 心として窓領域より大きい探索領域を設け，この中で対応 点を探索した。探索は対応点に打いてテンプレートと探索 領域の輝度分布が類似していることに着目し以下に示す SSDA 法 ${ }^{14)}$ に上り行った。すなわち，テンプレートの画 素の輝度值を $T_{i j}$ ，テンプレートを重称合わせた部分での 画素の輝度值を $S_{i j}$ とすると, 各画素の輝度値の差の絶対 值の総和 $R_{\mathrm{S}}$ は

$$
R_{\mathrm{S}}=\Sigma\left|T_{i j}-S_{i j}\right|
$$

でありテンプレートを探索領域中で順次移動させ， $R_{\mathrm{S}}$ が最小值となる点を対応点とみなするのである。ただし， この方法では最小荷重時と最大荷重時でき裂の形状が異な るために，き裂縁近傍で誤対応を生じる．現在はこの誤対 応を，前述したき裂開口変位の計測結果を用いてき裂領域 周辺の移動量と移動方向を考慮した制約条件と若干のマ ニュアル操作によって排除している。

き裂先端近傍の変位量解析の例を図 11 に示す。（a）は 1 荷重サイクル中の最小荷重負荷時に計測した画像で，こ の例ではき裂は完全に閉口し，画像中には認められない。

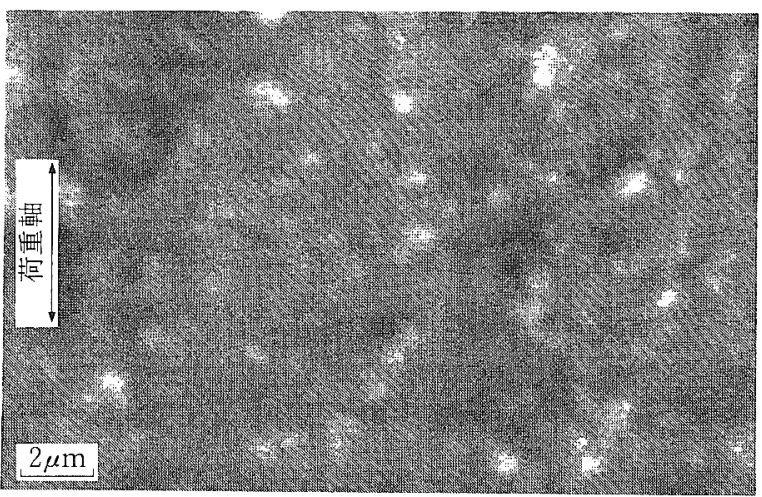

（a）最小荷重負荷時の SEM 画像

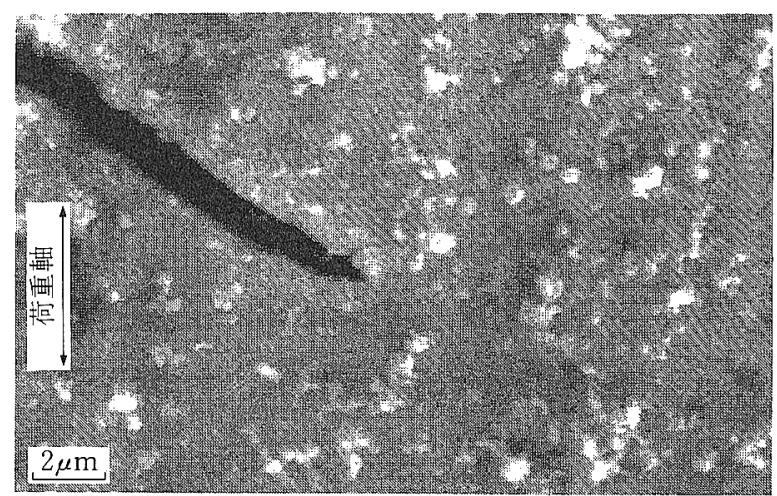

（b）最大荷重負荷時の SEM 画像

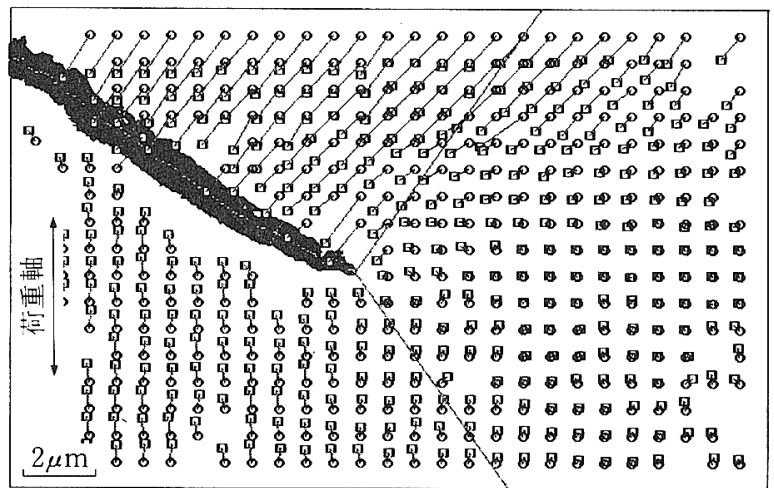

（c）疲労き裂先端近傍の変形場

図 11 疲学き裂先端近傍の变形の解析例

（b）以最大荷重負荷時に計測したものであり，（c）が両画 像間の SSDA 法による対応点の探索の結果である。空領 域として最大荷重時の画像中に, 20 画素間隔の格子点を 中心として設けた。図中丸印が最大荷重時の画像中の空領 域の中心であり，四角印がそれ対応する最小荷重時の画 像中の点である.そして，丸印と四角印を結ぶ線分の長さ が丸印の点に和ける变位量に相当する。な括，酸化マグネ シウム標点の無いところでは，特徵がなく対応ら゙けが一意 に決まらない場合があり，変位データの計測は行充なかっ た．四からわかるようにき裂先端後方ではすべり変形によ る移動量は大きく，また一様である。その一方，き裂先端 前方ではすべりは極めてわずかである。そして，両者の間 のすべり帯のところでは，き裂先端前方から後方に向かっ て徐々にすべり量が増加している。このすべりは図中に示 


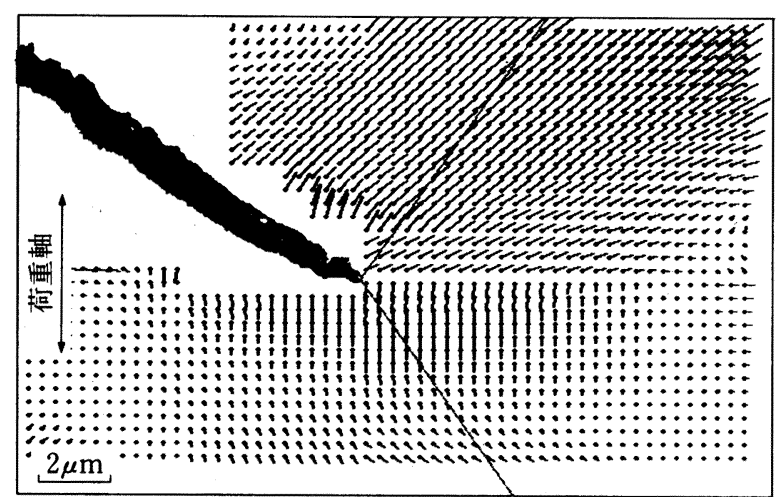

図 12 疲労き裂先端近傍の主せん断ひずみ場

したき裂先端を通る荷重軸直角方向に対して $\pm 55^{\circ}$ 傾いた すべり線よりも前方から始まっている.

次に, 2 画像間の対応点検索によって離散的に得られた き裂先端近傍の変位データをもとに主ひずみ，主せん断ひ ずみの同定を試みた。これらの同定には，変位の一次の微 分量が必要となるため，まず変位の連続分布を決定する必 要がある. ここでは，変位を荷重軸方向変位 $u$ とそれに 直角方向の変位 $v$ に分解し，それぞれに対して曲線をあ てはめることとした. 曲線の当てはめは，き裂周辺の変位 場がき裂先端を通るすべり線に沿って急激に変化している ことを考光，局所的な変化に柔軟に対応できる B-スプラ インによって表現されるスプライン関数 ${ }^{15)}$ をいて用い行っ た. スプライン関数による曲線の当てはめは, 節点の取り 方（個数括よび間隔）やB-スプラインの次数の影響を強 く受け, データ点での曲線との残差平方和を小さくするた めに, 単純にスプライン関数の次数を高くしたり, 節点の 数を增やすと, データ点とデータ点の間で当てはめた曲線 が振動を起こしてしまう，そこで，当てはめた曲線の妥当 性を定量的に評価するために赤池の情報基準量 (AIC) ${ }^{15)}$ を用いた。本解析では，計算量と精度のかねあいから 3 次 の B-スプラインを用い，節点の個数と場所は AIC がある 程度小さくなるようにマニュアル操作によって決定した。 き裂先端のすべり変形に寄与すると考兄られる主せん断ひ ずみ $\gamma_{x y}$ は, このようにして求められる変位曲線 $u$ 括よ びvから

$$
\gamma_{x y}=\frac{\partial u}{\partial y}+\frac{\partial v}{\partial x}+\left(\frac{\partial u}{\partial x}\right)\left(\frac{\partial u}{\partial y}\right)+\left(\frac{\partial v}{\partial x}\right)\left(\frac{\partial v}{\partial y}\right)
$$

に上り求められる. 前出の図 11 に示した例のデータに対 して求められた主せん断ひずみ分布を図 12 に示す. 図中 の点が計算を行った格子点であり, その点からの線の長さ がひずみ量を，線の方向が主ひずみの働く方向を示してい る.き裂先端前方領域ではほとんどひずみが現れていな い.また，せん断ひずみはき裂先端を通るすべり線上にの
み生じるのではなく，その近傍の比較的広い範囲で生じて いることがより明らかとなっている.

\section{4. おわ $ク に$}

電界放射型走査電子顕微鏡内疲労試験装置により得られ る繰返し荷重下のき裂画像を高速でュンピュータに取り込 む画像信号計測システムならびに变位の定量解析のための 画像処理システムを構築した。このシステムを用いたき裂 先端開口変位の測定やき裂先端近傍の変形場およびひずみ 場の定量解析により，非定常な変動荷重下で現れる疲労き 裂進展挙動の過渡的現象の機構が明らかになってきてお り，さらに解析を続けることにより疲労き裂進展機構に関 する多くの知見が得られると期待される.

\section{参考 文 献}

1) P. Neumann: The Geometry of Slip Processes at a Propagating Fatigue Crack II, Acta Met., 22, 1167, (1974).

2) P. Neumann, H. Verhoff and H. Fuhlrott : On the Mechanisms of Fatigue Crack Growth, Proc. ICF-4, Waterloo, 2, 1313, (1977).

3) D. L. Davidson and J. Lankford: Dynamic, Real-Time Fatigue Crack Propagation at High Resolution as Observed in the Scanning Electron Microscope, ASTM STP 675, (1979) 277.

4) D. L. Davidson and J. Lankford : Mixed-mode Crack Opening in Fatigue, Mat. Sci. and Eng., 60, (1983) 225.

5）菊川真, 城野政弘, 安達正晴: 疲労き裂進展過程の走查電 子䫒微鏡による連続観察とき裂進展機構,材料, 27 (1978) 853 .

6）菊川 面, 城野政弘, 岩橋 稔, 市川光秋, 上杉暢彦: 進展 寸る疲労き裂の電界放射型走査電子䫒徽鏡による動的直接観 察, 材料, 31 (1982) 669 .

7）城野政弘，宋 智浩，岡部雅彦，上杉暢彦，大垣雅由，江口 直紀：発生初期微小き裂進展から弾塑性巨視疲労き裂までの き裂進展速度と開閉口挙動，材料，33（1984）560.

8）城野政弘, 宋 智浩, 後藤邦夫：進展する疲労き裂の電界放 射形走査電子顕徽鏡による動的直接観察，日本機械学会論文 集, A-51（1985） 1453

9）城野政弘，宋 智浩，後藤邦夫，山田真治：疲労き裂進展の 動的直接観察と疲労き裂進展機構（進展速度とき裂先端開口 変位の関係), 材料, 35 (1986) 918.

10）城野政弘，菅田 淳：変動荷重下の疲労き裂進展の走査電子 顕微鏡による直接観察とき裂進展機構, 材料, 39 (1989) 1119.

11）城野政弘, 菅田 淳, 宝田真一, 大久保啓之, 駒城倫哉：走 查電子䫒微鏡による疲労き裂材料進展挙動の動的直接観察と 画像処理技術の開発，材料，39（1990） 1583.

12）城野政弘, 菅田 淳, 吾妻健夫：疲労き裂先端近傍変形の画 像処理技術による定量解析，日本機械学会論文集，A-57, 541 (1991) 2215 .

13）城野政弘，菅田 淳，濱崎俊彰：電界放射型走查電子影徽篭 による 2 段繰返し変動荷重下の疲労き裂進展挙動の直接観察, 材料, 40 (1991) 1428 .

14）駒井謙治郎：画像処理技術を用いた破面解析の現状，日本機 械学会関西支部第 167 回講習会教材，(1989） 49.

15）市田浩三, 吉本富士市：スブライン関数とその応用，教育出 版, (1979). 